\title{
Distribution of carabid Beetles (Coleoptera, Carabidae) across a Boreal Forest-Clearcut Ecotone
}

\section{Heliölä, J.}

Blackwell Science, Inc.

2001

Heliölä, J., Koivula, M. and Niemelä, J. 2001. Distribution of carabid Beetles (Coleoptera, Carabidae) across a Boreal Forest-Clearcut Ecotone. Conservation Biology 15: 370-377.

http://hdl.handle.net/1975/254

Downloaded from Helda, University of Helsinki institutional repository.

This is an electronic reprint of the original article.

This reprint may differ from the original in pagination and typographic detail.

Please cite the original version. 


\title{
Distribution of Carabid Beetles (Coleoptera, Carabidae) across a Boreal Forest-Clearcut Ecotone
}

\author{
JANNE HELIÖL̈̈, MATTI KOIVULA, AND JARI NIEMELÄ* \\ Department of Ecology and Systematics, Division of Population Biology, P.O. Box 17 , \\ FIN-00014 University of Helsinki, Helsinki, Finland
}

\begin{abstract}
We studied the occurrence of carabid beetles (Coleoptera, Carabidae) in boreal forest fragments, their edges, and adjacent clearcuts in central Finland. Beetles were collected with pitfall traps along transects extending $60 \mathrm{~m}$ from the edge into clearcuts and $60 \mathrm{~m}$ into forest interior. Our main findings were that (1) species richness was significantly bigher in the clearcut than in the forest fragments, (2) clearcuts bosted many open-habitat species, which increased overall species ricbness in these sites, (3) carabid assemblages in the edges were more similar to forest assemblages than to those found in the clearcuts, (4) no edge specialists were found, and (5) open-babitat species did not penetrate into the forest fragments from the clearcut. Be cause forest specialists occurred all the way to the edge on the forest side, it seems that edge effects per se do not adversely affect these species, at least in the short term. In the long term, bowever, babitat conditions in the edges may deteriorate for interior species because of trees falling over in strong winds, thereby reducing the size of the fragments and widening the edge zone.
\end{abstract}

Distribución de Escarabajos Carábidos (Coleoptera, Carabidae) a lo Largo de un Ecotono de Bosque Boreal - Zona Talada

Resumen: Estudiamos la presencia de escarabajos carábidos (Coleoptera, Carabidae) en fragmentos de un bosque boreal, de sus bordes y de zonas taladas adyacentes en Finlandia central. Los escarabajos fueron colectados usando trampas cubiertas a lo largo de transectos que se extendian desde $60 \mathrm{~m}$ del borde hacia el área de tala y $60 \mathrm{~m}$ bacia el interior del bosque. Nuestros resultados principales fueron: (1) la riqueza de especies fue significativamente mayor en la zona talada que en los fragmentos de bosque, (2) las zonas taladas bospedaron mucbas especies de bábitat abierto, lo cual incrementó la riqueza general de especies en estos sitios, (3) los ensamblajes de carábidos en los bordes fueron más similares a los ensamblajes del bosque, que aquellos en las zonas taladas, (4) no se encontraron especialistas de borde, y (5) las especies de hábitat abierto no penetraron de las zonas taladas bacia los fragmentos de bosque. Debido a que los especialistas de bosque aparecieron a todo lo largo del borde en el lado del bosque, aparentemente los efectos de borde en sí no afectan adversamente a estas especies, al menos a corto plazo. Sin embargo, a largo plazo las condiciones del hábitat en los bordes podrian deteriorar para las especies del interior, debido a la caída de árboles ocasionada por vientos fuertes, lo cual reduce el tamaño de los fragmentos, ampliando la zona de borde.

\section{Introduction}

Fragmentation and habitat loss are among the most im portant causes of species decline worldwide (c.g., Haila

\footnotetext{
*Address correspondence to J. Niemelä, email jariniemela@belsinkifi Paper submitted September 27, 1999; revised manuscript accepted May 24,2000
}

370 et al. 1994; Murcia 1995; Didham et al. 1996; Didham $1997 a, 1997 b$ ). In many parts of the boreal region, logging has transformed the forest landscape into a patchwork of forest remnants of various sizes that are isolated from one another by clearcuts (Esseen et al. 1997). In Finland, for instance, forest fragmentation has already caused species declines and probably local extinctions (Rassi et al. 1992; Siitonen \& Martikainen 1994; Niemelä 1997). 
One consequence of fragmentation and associated habitat loss is decreasing fragment size, which leads to a decreasing proportion of interior habitat and increasing proportion of edge (Ranney et al. 1981; Harris 1984; Murcia 1995; Ranta et al. 1998; Haila 1999; Matlack \& Litvaitis 1999). Changes in abiotic and biotic conditions in the edge compared with the intact habitat are collectively called edge effects. These effects are many, including changes in wind, humidity, radiation, predation, parasitism, and species interactions (Saunders et al 1991; Andrén 1995; Chen et al. 1995; Murcia 1995; Risser 1995; Donovan et al. 1997; Voller 1998). Increased levels of human-induced disturbance at habitat edges also affect species composition (Kruger \& Lawes 1997).

To counteract the negative effects of edges, it is important to understand how species respond to conditions in habitat edges (Haila et al. 1994). Forest edges are the preferred habitat of many vertebrate species, such as ungulates (Voller 1998). Furthermore, forest edges har bor a rich invertebrate fauna (e.g., Helle \& Muona 1985; Jokimäki et al. 1998), but few of these species appear to be edge specialists (Didham 1997b). Invertebrate assemblages in edges are mixtures of species found on either side of the edge zone (Kotze \& Samways 1999). This implies that edges of forest fragments are easily invaded by invertebrate species from the surrounding matrix and that some species may continue through the edge "filter" into the forest interior (Spence et al. 1996). Small forest fragments with a high proportion of edge habitat are particularly vulnerable to invasion by species from the surrounding matrix (Bauer 1989; Halme \& Niemelä 1993; Usher et al. 1993; Burke \& Goulet 1998). Furthermore, edge habitat is unsuitable for species requiring interior habitat (Demaynadier \& Hunter 1998; Stevens \& Husband 1998; von Sacken 1998), and consequently such species may be lost if fragments become too small (Haila 1999). Forest managers should minimize adverse edge effects by, for example, leaving fragments large enough to maintain specialists of the forest interior (Spence et al. 1996; Burke \& Goulet 1998; von Sacken 1998).

We examined the distribution of carabid beetles in "hard edges" between mature spruce forest and adjacent clearcuts in central Finland. As recommended by Meiners and Pickett (1999), we studied edges as gradients that included, in addition to the edge zone, both disturbed (clearcut) and undisturbed (mature forest) habitat. We focused on the following questions: (1) Are forest-interior species sensitive to the forest edge, as shown for salamanders and anurans (Demaynadier \& Hunter 1998) and small mammals (Stevens \& Husband 1998)? (2) Do open-habitat species invade forest fragments, as suggested by Halme and Niemelä (1993)? (3) What are the differences in carabid assemblages between mature forest patches and clearcut patches?

\section{Methods}

The study area is located in Northern Häme (southcentral Finland, approximately lat $61^{\circ} \mathrm{N}$, long $24^{\circ} \mathrm{E}$ ) in the municipalities of Keuruu, Kuorevesi, Längelmäki, and Orivesi. The study sites are dominated by 80 - to 100 year-old spruce (Picea abies), with some pines (Pinus sylvestris) and birches (Betula spp.) among the spruce. The field layer is dominated by blueberry (Vaccinium myrtillus) and lingonberry (Vaccinium vitis-idaea), and the ground layer is dominated by mosses.

The study sites of approximately 2 ha each were established to examine the effects of modified forest harvest. ing methods on biodiversity. We used six of the sites, which represented two of the five harvesting methods examined: (1) three sites were treated with traditional clearcutting (all merchantable trees removed) and (2) three sites were treated by modified clearcutting in which three or four groups of 20-30 trees each were retained per hectare. The traditionally cut sites faced west and the modified ones east, but this had no effect on carabid assemblages. The distances between the six sites were $500 \mathrm{~m}$ or more. The sites were harvested in the winter of 1995 1996, and our edge study was conducted in the summer of 1997 . The contrast between the clearcut and the mature forest was strong, and the edge could be considered a hard edge (Demaynadier \& Hunter 1998).

Pitfall traps were used to collect beetles (Greenslade 1964; Spence \& Niemelä 1994). Traps were plastic jars (diameter $65 \mathrm{~mm}$, depth $70 \mathrm{~mm}$ ) partly filled with $20 \%$ ethylene glycol solution. A plastic roof of $10 \times 10 \mathrm{~cm}$ was placed a few centimeters above each trap to prevent flooding from rainwater. The trapping period covered most of the growing season (15 May-17 September), and the traps were emptied and serviced once a month. In spite of the 4-week servicing intervals, the traps and their catches remained in good condition, and few traps were lost due to flooding by water or debris. Furthermore, few small mammals or frogs fell into the traps.

We studied edges as gradients that included, in addition to the edge, disturbed (clearcut) and undisturbed (mature forest) habitat, as recommended by Meiners and Pickett (1999). Our gradient extended from a point $60 \mathrm{~m}$ from the edge into the forest interior and through the edge to a point $60 \mathrm{~m}$ into the clearcut. Carabid samples from four traps $4-5 \mathrm{~m}$ apart arranged in a line (trapline) parallel to the edge were pooled and used in the analyses. One trap line of four traps was placed along the edge between the mature forest and the clearcut. The other trap lines ran from the edge into the forest and similarly into the clearcut, with traps at $15,30,45$, and $60 \mathrm{~m}$ from the edge. Each of the six study sites had nine trap lines, for a total of 36 traps per site (four lines in the forest, one line in the edge, and four lines in the clearcut). In the modified clearcuts, we avoided groups of retained trees when we placed the trap lines. 
We used a 60-m distance from the edge for two reasons. First, at this distance into the forest most edge effects are dampened (Harris 1984; Kapos 1989; Murcia 1995; Demaynadier \& Hunter 1998). Second, in both the clearcut and the forest, the last trap line was close to the center of the habitat, and going farther would have brought the opposite forest edge too close.

We used Kruskall-Wallis nonparametric analysis of variance (ANOVA) to examine the species richness and abundance of carabids between the two treatments (traditional clearcutting and modified clearcutting) and among different distances along the gradient from forest interior through the edge to the clearcut. Species richnesses were standardized by rarefaction to remove the effects of differing beetle abundances (Ludwig \& Reynolds 1988; Krebs 1989). We used Scheffe's test for post-hoc pairwise comparisons. For the ANOVA we divided the trap lines into three distance groups (forest interior, trap lines 30,45 , and $60 \mathrm{~m}$ inside the forest; edge, trap lines $15 \mathrm{~m}$ inside the forest, at the edge, and $15 \mathrm{~m}$ into the clearcut; and clearcut, trap lines 30,45 , and $60 \mathrm{~m}$ into the clearcut).

A cluster analysis (group-average linking algorithm with Czekanowski-Sørensen similarity metric) was used to compare carabid assemblage structure among the three distance groups described above (Ludwig \& Reynolds 1988; Krebs 1989). The value of the similarity metric ranges between 0 , for no species shared, and 1 , for identical samples. We used the BIODIV software package to perform the cluster analysis (Baev \& Penev 1995).

Ground and field-layer vegetation cover, litter, and logging residue were estimated within a circle $3-\mathrm{m}$ in diameter that was placed in the center of each four-trap line. These measurements were used in a redundancy analysis (RDA; Jongman et al. 1995) to study the relationship between carabid occurrence and their environment. We excluded from the RDA analysis environmental variables with more than $75 \%$ o values and those with some (usually one to three) extreme values because of their potentially strong and misleading effect on the analysis. We also excluded from the analysis carabid species with only one individual. After these amendments we included in the analysis ten environmental variables and 27 carabid species, and we used data transformed by $\ln (x+1)$. We centered by species when running the analysis and did the RDA analysis using the CANOCO 1.0 software package (ter Braak \& Smilauer 1998).

\section{Results}

Changes in Community Structure across the Edge

There were no statistically significant differences in carabid species abundance ( $U=45.00$, df $=1, p=0.691$ )

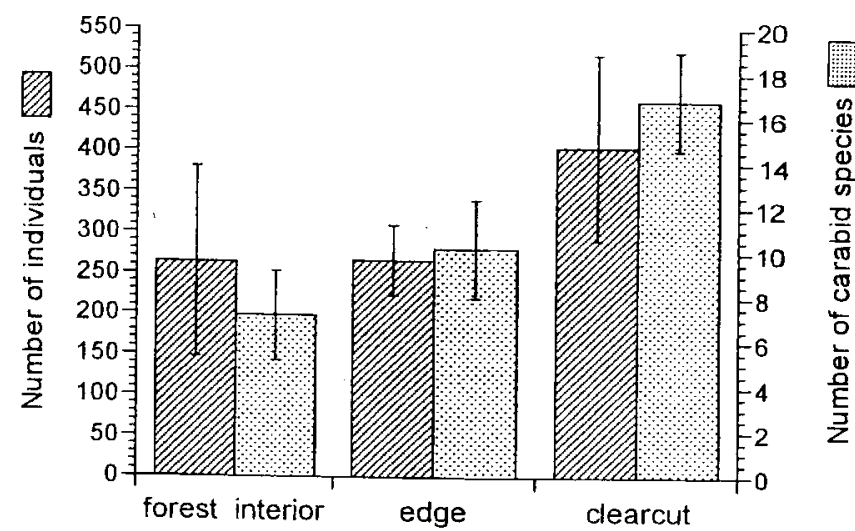

Figure 1. Average number of carabid individuals and species with 95\% confidence interval in the forest interior (traps 30-60 m inside the forest fragment), edge (traps $15 \mathrm{~m}$ inside the forest, at the edge, and $15 \mathrm{~m}$ into the clearcut), and in the clearcut (30-60 $\mathrm{m}$ into the clearcut).

or richness ( $U=30.00$, df $=1, p=0.354$ ) between the traditionally clearcut sites and the retention tree cutting. Furthermore, there were no differences in species richness or abundance in relation to the exposure of the edge. Thus, we hereafter use the pooled data from the two harvesting types.

Species richness differed significantly between forest interior, edge, and clearcut $(U=8.56$, df $=2, p=$ 0.014 ) (Fig. 1). According to Scheffe's post hoc test, species richness was significantly higher in the clearcuts than in the forest interiors and edges, whereas species richness in edges and forest interiors did not differ $(p>$ $0.05)$. There were no statistically significant differences in carabid abundance between forest interior, edge, and clearcut ( $U=3.71$, df $=2, p=0.157$ ) (Fig. 1).

According to the cluster analysis, edges grouped to-

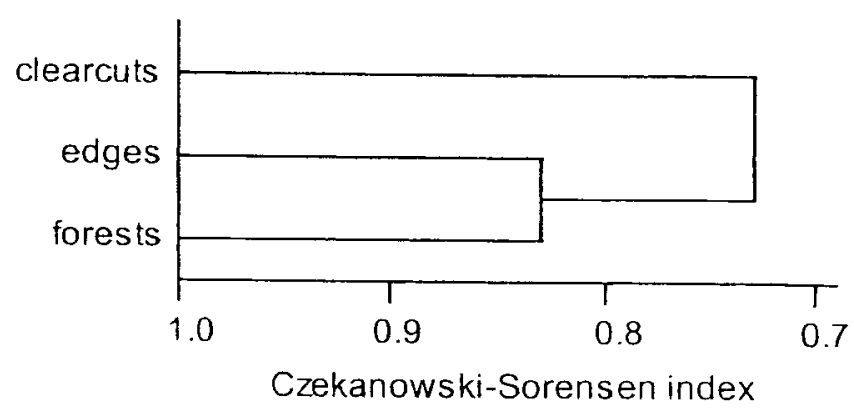

Figure 2. Cluster analysis with Czekanowski-Sorensen index (group-average linking algorilbm) of the carabid assemblages in the forest interior (traps $30-60 \mathrm{~m}$ inside the forest), at the edge (traps from $15 \mathrm{~m}$ into the forest, at the edge, and $15 \mathrm{~m}$ into the clearcut), and in the clearcut (traps 30-60 $\mathrm{m}$ into the clearcut). 
gether with forest interiors, indicating that carabid assemblages in the edges were more similar to forest assemblages than to those in the clearcuts (Fig. 2). Similarity within these clusters was high (>73\%).

\section{Species Occurrence across the Edge}

A total of 5609 carabid beetles representing 34 species was captured. Calatbus micropterus was the most abundant species, with 3373 individuals (60\% of the total sample), and Pterosticbus oblongopunctatus was the second most abundant species, with 1363 individuals ( $24 \%$ of the total sample) (Table 1 ).

Except for two scarce species (Amara famelica, Leis-

Table 1. Pooled numbers of carabid individuals collected in the six sites divided into forest trap lines, edge trap lines, and clearcut trap lines.

\begin{tabular}{|c|c|c|c|}
\hline \multirow[b]{2}{*}{ Scientific name (abbreviation) } & \multicolumn{3}{|c|}{ Number of individuals* } \\
\hline & forest & edge & clearcut \\
\hline Agonum fuliginosum (Agonfuli) & 45 & 37 & 132 \\
\hline A. mannerbeimii (Agonmann) & 16 & 5 & 7 \\
\hline A. sexpunctatum (Agonsexp) & 0 & 1 & 11 \\
\hline Amara brunnea (Amarbrun) & 3 & 4 & 8 \\
\hline A. famelica & 0 & 1 & 0 \\
\hline A. lunicollis & 0 & 0 & 5 \\
\hline Bembidion bruxellense & 0 & 0 & 1 \\
\hline B. lampros (Bemblamp) & 0 & 4 & 18 \\
\hline Calathus micropterus (Calamicr) & 1253 & 1051 & 1069 \\
\hline C. cancellatus (Caracanc) & 1 & 2 & 9 \\
\hline C. glabratus (Caraglab) & 15 & 34 & 36 \\
\hline C. bortensis (Carahort) & 12 & 3 & 3 \\
\hline Cicindela campestris & 0 & 0 & 1 \\
\hline Cycbrus caraboides (Cychcara) & .18 & 5 & 6 \\
\hline Dyscbirius globosus & 1 & 0 & 0 \\
\hline \multicolumn{4}{|l|}{ Harpalus quadripunctatus } \\
\hline (Harpquad) & 0 & 9 & 12 \\
\hline Leistus ferruginetus & 0 & 0 & 2 \\
\hline L. terminatus & 0 & 1 & 0 \\
\hline Miscodera arctica & 0 & 0 & 1 \\
\hline Notiopbilus biguttatus (Notibigu) & 13 & 13 & 37 \\
\hline N.palustris & 0 & 0 & 5 \\
\hline Patrobus assimilis (Patrassi) & 17 & 7 & 20 \\
\hline Pterosticbus adstrictus (Pteradst) & 0 & 7 & 110 \\
\hline P. cupreus (Ptercupr) & 0 & 1 & 4 \\
\hline P. diligens (Pterdili) & 6 & 6 & 3 \\
\hline P. niger (Pternige) & 0 & 4 & 8 \\
\hline P. nigrita (Pternigr) & 0 & 1 & 26 \\
\hline P. oblongopunctatus (Pteroblo) & 171 & 370 & 822 \\
\hline P. strenuus (Pterstre) & 1 & 3 & 17 \\
\hline P. vernalis & 0 & 0 & 3 \\
\hline$P$. versicolor (Ptervers) & 0 & 3 & 2 \\
\hline Trecbus rubens (Trecrube) & 1 & 0 & 1 \\
\hline T. secalis (Trecseca) & 9 & 26 & 49 \\
\hline Tricbocellus placidus & 0 & 0 & 1 \\
\hline Number of individuals & 1582 & 1598 & 2429 \\
\hline Number of species & 16 & 24 & 31 \\
\hline
\end{tabular}

${ }^{*}$ Forest, traps 30-60 $\mathrm{m}$ into the forest interior; edge, traps $15 \mathrm{~m}$ into the forest, lines on the edge, and traps $15 \mathrm{~m}$ into the clearcut: clearcut traps $30-60 \mathrm{~m}$ into the clearcut. tus terminatus), none of the species was restricted to the edge zone or was clearly more abundant there than elsewhere (Table 1). Nevertheless, many species that were abundant in the clearcut occurred in low numbers in the edge zone (e.g., Bembidion lampros, Harpalus quadripunctalus, Pterosticbus adstrictus, $P$. nigrita) (Table 1). Most of these species require open habitat (Lindroth 1985, 1986). Because only single individuals of these species were found in the forest interior (30-60 $m$ into the forest), it is evident that open-habitat species entered the forest only sporadically from the clearcut. For instance, the most abundant colonizer, $P$. adstrictus, decreased drastically from the center of the clearcut toward the edge and did not penetrate the forest at all (Fig. 3).

\section{Environmental Variables and Carabid Occurrence}

There were dramatic differences in the field and groundlayer vegetation between the forest and the clearcut (Fig. 4). Most changes occurred right in the edge, although there was some logging residue and bare soil in the forest close to the edge. In the field layer, dwarf shrubs, especially blueberry (Vaccinium myrtillus) and lingonberry ( $V$. vitis-idaea), decreased from a cover of $30-40 \%$ in the forest to approximately $10 \%$ in the clearcut. Grasses (Deschampsia flexuosa, Calamagrostis sp.) and fireweed (Epilobium angustifolium), on the other hand, were more common in the clearcut than in the forest. In the ground layer, mosses (Pleurozium spp., Dicranum spp.) were common in the uncut forest, whereas in the exposed clearcuts they did not thrive. Also the moisture-dependent Sphagnum mosses were scarce in the clearcuts. Exposed soil, logging residue, and needle lit-

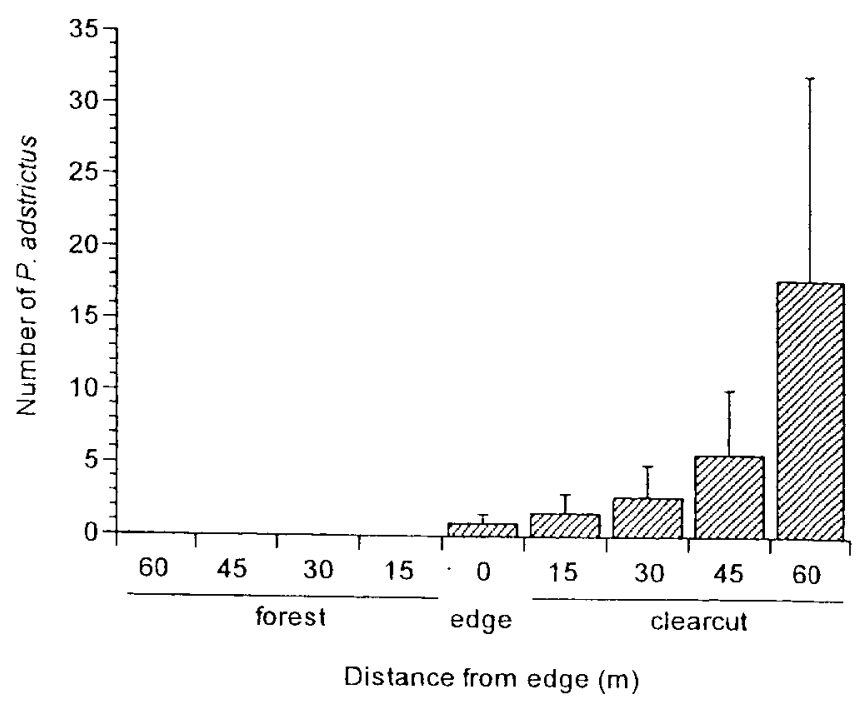

Figure 3. Number of Pterostichus adstrictus in the trap lines at different distances from the edge. Average catch from the six sites with 95\% confidence interval. 


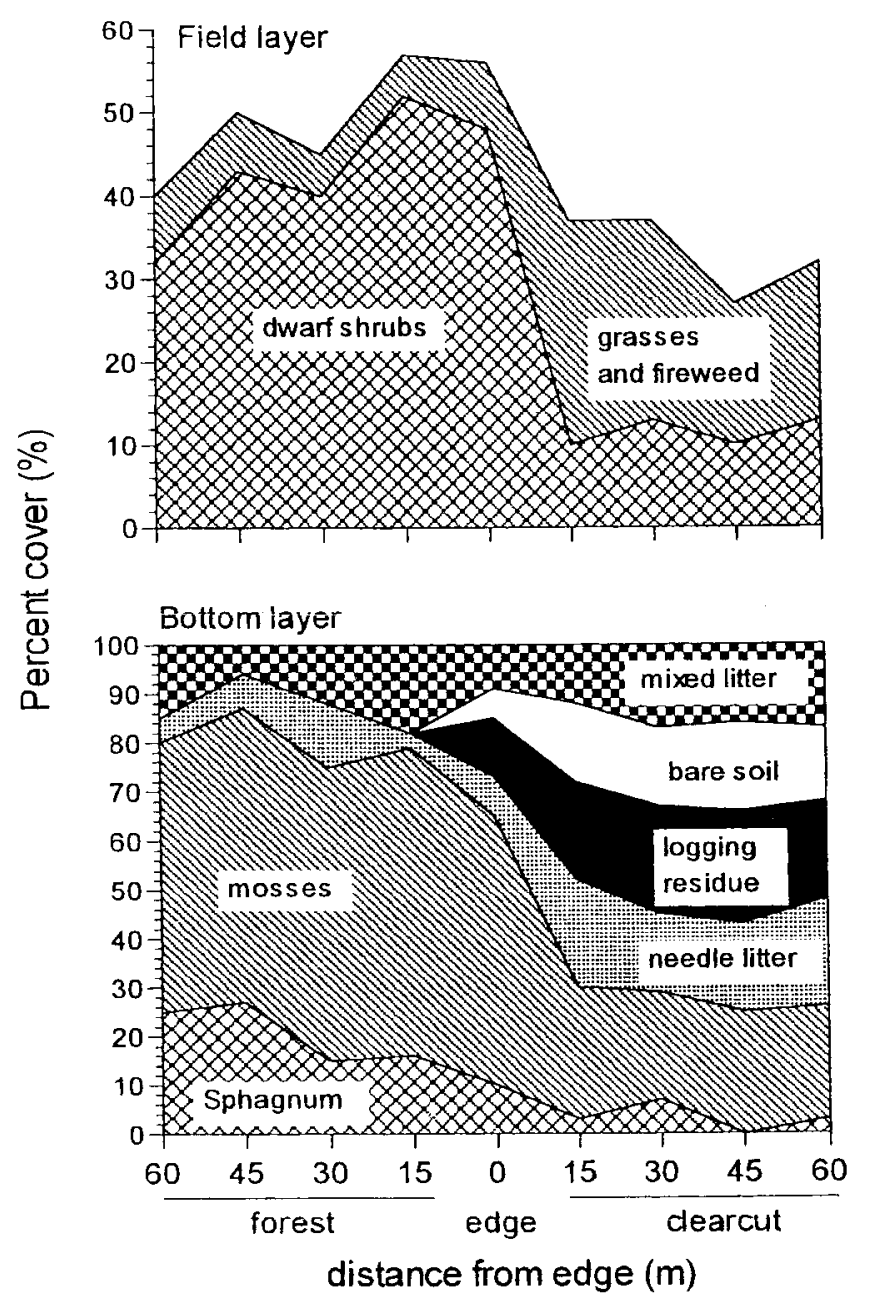

Figure 4. Percent cover of dwarf shrubs (mainly Vaccinium myrtillus and Vaccinium vitis-idea) and grasses in the field layers, and Sphagnum mosses, other mosses, needle litter, logging residue, bare soil, and mixed needle and leaf litter in the bottom layer. All six sites are combined.

ter from the residue covered a high proportion of the clearcut (Fig. 4).

In the redundancy analysis based on environmental variables and the trap line-specific samples, the carabid species had eigenvalues in the first four axes of 0.195 , $0.098,0.030$, and 0.021 , respectively (Fig. 5). The first two axes explained $29.3 \%$ of the total variance in occurrence of carabid species and $76.5 \%$ of the variance in the relationship between carabid species and the environment. We analyzed the statistical significance of the axes by Monte-Carlo randomization. The trace value of all axes was $0.383(F=2.665, p=0.005,199$ permutations), indicating that the environmental variables and carabid species had a highly significant relationship.

The first axis of the ordination (axis 1, Fig. 5) indicated a division between trap lines located in the mature forest (right side of the ordination space: tall spruces, mixed litter, mosses, Vaccinium spp.) and those located in the clearcut (left side: logging residue, stumps, needle litter). Also, the cover of grasses, an indication of early successional stage, and the cover of exposed soil, indicating amount of mechanical soil preparation, were located toward the left side of the ordination space (Fig. 5). The second axis (axis 2) seems to indicate moisture: the percent cover of Sphagnum mosses correlated strongly and positively with this axis. On the contrary, the cover of forest mosses correlated slightly negatively with Sphagnum, indicating somewhat drier conditions.

In the RDA ordination, almost every carabid species was located left of the origin, indicating that most of the species were positively associated with habitat variables in the clearcut (Fig. 5). For instance, Pterosticbus adstrictus and $P$. oblongopunctatus correlated highly positively with logging residue and needle litter. Thus, it is possible that some carabid species benefit from the increased structural elements on the forest floor following clearcutting. In contrast, forest specialist species were located in the lower part of the ordination space. These species (e.g., C. hortensis and $C$. caraboides) did not correlate with variables associated with clearcuts, but they correlated positively with, for instance, the cover of forest mosses, Vaccinium dwarf shrubs, and the amount of large spruce trees. The third group of carabids, located in the upper part of the plot, consisted of species most often caught from moist patches characterized by the occurrence of Sphagnum mosses (c.g., Agonum mannerbeimii, A. fuliginosum, Pterostichus diligens, and Patrobus assimilis). These species occurred in the forest and clearcut (Table 1; Fig. 4). Carabus glabratus, $C$. micropterus, and $P$. niger correlated negatively with Sphagnum.

\section{Discussion}

\section{Carabid Responses to Forest Edges}

The main findings of our study were that (1) carabid assemblages in the edges were more similar to assemblages in the forest interior than to those in the clearcuts; (2) carabids did not avoid the edge zone on the side of the forest, but there were no edge specialists; (3) although species richness and carabid abundance were high in the clearcuts, open-habitat species only occasionally penetrated into the forest interior from the clearcut; and (4) some forest species were less abundant in the clearcuts and may have been suffering from frag. mentation of mature boreal forest.

The finding that carabid samples from the edges were similar to those from the forest trap lines corroborates results from forest-grassland edges in South Africa (Kotze \& Samways 1999). Furthermore, both our results and those 


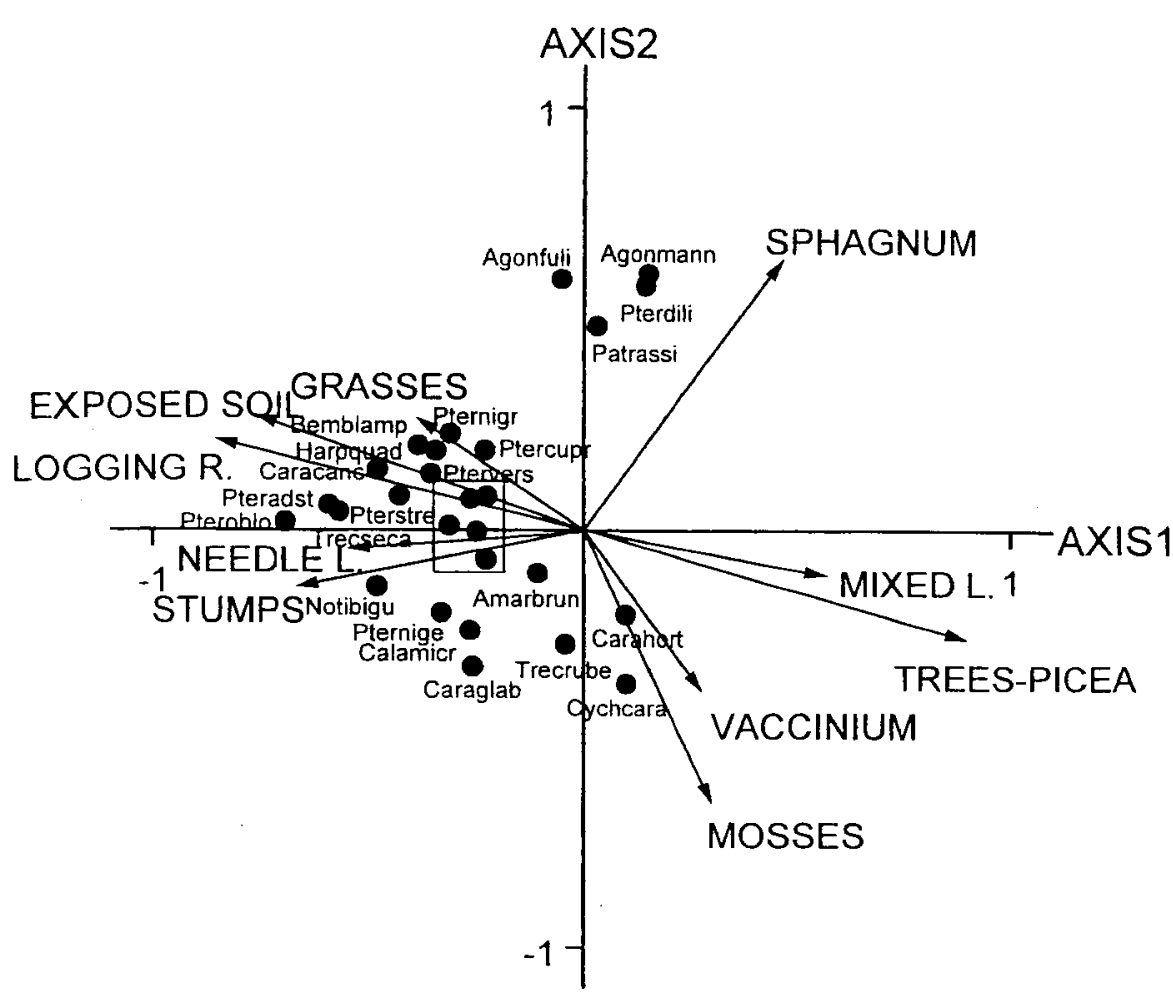

Figure 5. The RDA ordination for carabids and 10 environmental variables. Carabid species are marked with black circles and the environmental variables with arrows. Trees-picea is mature spruce individuals (minimum $20 \mathrm{~m}$ beight) per $78.5 \mathrm{~m}^{2}$. The other variables are percentage coverages per $28.3 \mathrm{~m}^{2}$. Label explanations: Grasses, Calamagrostis, Deschampsia, etc,; logging r, logging residue; mixed $l$, mixed deciduous and needle litter; mosses, forest-inhabiting mosses; needle $l$, needle litter; exposed soil, visible sand layer created by mechanical soil preparation; sphagnum, Sphagnum mosses; Vaccinium, V. vitis-idaea and V. myrtillus dwarf shrubs. Box includes five carabid species: Agonum sexpunctatum, Amara lunicollis, Leistus ferrugineus, Notiophilus palustris, and Pterostichus vernalis. Abbreviations of the carabid species are listed in Table 1. of Kotze and Samways (1999) show that the edge was abrupt for carabids. In our study, forest species occurred right to the edge on the forest side, and it appears that the physical conditions in the edges did not negatively affect forest-dwelling carabids. As our analyses showed, field and ground-layer vegetation remained virtually intact close to the forest edge, which may have contributed to the maintenance of populations of forest carabids near the edge. This result, however, may not be applicable to other taxa. For instance, some forest-dwelling salamanders and anurans in the United States (Demaynadier \& Hunter 1998) and small mammals in Brazil (Stevens \& Husband 1998) avoid forest edges.

As in boreal Canada (Spence et al. 1996), no carabid species were restricted to the edge in our study. Thus, it seems that there are no edge species among boreal forest carabids. In temperate oak-hornbeam forest in Hungary, however, several carabid species occurred exclusively at the forest edge, indicating that these habitats are important for the maintenance of carabid diversity (Magura \& Tothmeresz 1997). The different responses of carabids to edges may be attributed to differences in vegetation. Our edges and those studied by Spence et al. (1996) were hard, abrupt, and created by clearcutting, whereas those studied by Magura and Tothmeresz (1997) were gradual, with abundant bushes.

In our study, more carabid species and individuals were collected from clearcuts than from forests. Most of the species found in the clearcuts were specialists of open habitats (Lindroth 1985, 1986), but some forest generalists, notably $P$. oblongopunctatus and $T$. secalis, were more common in the clearcuts than in the forests. The open, dry, and warm clearcuts are favored by many carabid species occurring in grasslands and other similar habitats; only a few species have adapted to the dark and cool spruce forest (Niemelä 1993). In addition to carabids (Niemelä et al. 1988, 1993, 1994; Halme \& Niemelä 1993; Haila et al. 1994; Spence et al. 1996), the phenomenon of high abundance in clearcuts appears to be the rule for spiders (Pajunen et al. 1995), ants (Punttila et al. 1991, 1994), and butterflies (Väisänen 1995). But Kotze and Samways (1999) reported from Afromontane forest-grassland ecotones in South Africa that, whereas ants were more abundant in the grassland, carabids were more abundant in adjacent forests, perhaps because of competitively superior ants. In our study, there was a negative correlation between the number of red wood ants and carabids in the traps $(r=-0.31, p=$ 0.02 ). This correlation does not necessarily indicate competition; it may be related to different microhabitat preferences among ants and carabids.

Although many open-habitat carabid species were common in our clearcuts, they rarely penetrated into the forest. Similarly, in Switzerland only 1 of 15 carabid 
species occurred commonly in both a grassland patch and the surrounding forest edge (Hänggi \& Baur 1998) Contrary to these studies, some carabid species classified in literature as open-habitat specialists (e.g., Bembidion grapei and $P$. adstrictus) occurred 20-40 $\mathrm{m}$ into the forest in a Canadian study (Spence et al. 1996).

\section{Conservation Implications}

Populations of forest-dwelling carabids appeared not to be affected negatively by the edge zone, because beetle numbers did not decrease near the edge. A similar observation was made in Canada (Spence et al. 1996). Although these findings suggest that edges do not have much negative effect on forest carabids, continued fragmentation and decreases in the size of fragments may in the long run threaten currently viable populations. For instance, small forest fragments are more vulnerable to invasion by open-habitat species from the surrounding regenerating forests (Halme \& Niemelä 1993; Burke \& Goulet 1998). Furthermore, other taxa may be more sensitive to edge. Bark beetles (Coleoptera, Scolytidae) were less common in forest edges than in interior forest in Finland (Peltonen \& Heliövaara 1998). Similarly, in Amazonian rain forest, beetle abundances were lower in the edge and peaked $26-105 \mathrm{~m}$ from the edge toward forest interior (Didham 1997b); however, that study did not examine the fragments' surroundings. In our study there appeared to be an edge effect on the side of the clearcuts, because some open-habitat species decreased near the edge.

Although forest species were not negatively affected by edge effects, they may suffer from isolation effects caused by fragmentation (see also Burke \& Goulet 1998). Flightless forest specialists, such as Carabus bortensis and Cycbrus caraboides, may perish when attempting to cross clearcuts. We found some individuals of these species in the clearcuts, but Halme and Niemelä (1993) reported that $C$. caraboides was virtually absent from open habitat and from forest fragments of $<20$ ha and that $C$. bortensis was scarce in fragments of $<3$ ha. Similarly, in Canada, the local cychrine species Scaphinotus marginatus was restricted to mature forest (Spence et al. 1996). To maintain populations of such species in the landscape, it is imperative to preserve large, intact forest tracts (Halme \& Niemelä 1993). These conclusions are supported by findings from the Amazonian rainforest, where a forest area of 500-1000 ha is required for maintaining an intact terrestrial invertebrate assemblage (Didham 1997b).

We found that numbers of carabids did not decrease toward the edge in the forest fragment. This pattern may change over the years, because forest fragmentation started by humans appears to continue through natural forces. Trees at edges tend to fall over in strong winds, reducing the area of core habitat and opening up the edge zone, thereby increasing the permeability of the edge for open-habitat species. This process has already started in our forest fragments.

\section{Acknowledgments}

This study was funded by the Academy of Finland and the Finnish Biodiversity Research Programme. We thank J. Kotze for comments.

\section{Literature Cited}

Andrén, H. 1995. Effects of landscape composition on predation rates at habitat edges. Pages $225-255$ in L. Hansson, L. Fahrig, and G. Merriam, editors. Mosaic landscapes and ecological processes. Chapman \& Hall, London.

Baev, P. V., and L. D. Penev. 1995. BIODIV: program for calculating biological diversity parameters, similarity, niche overlap, and cluster analysis. Exeter Software, New York.

Bauer, L. C. 1989. Moorland beetle communities on limestone 'habitat islands'. I. Isolation, invasion and local species diversity in carabids and staphylinids. Journal of Animal Ecology 58:1077-1098.

Burke, D., and H. Goulet. 1998. Landscape and area effects on beetle assemblages in Ontario. Ecography 21:472-479.

Chen, J., J. F. Franklin, and T. A. Spies. 1995. Growing-season microclimatic gradients from clearcut edges into old growth Douglas-fir forests. Ecological Applications 5:74́-86.

Demaynadier, P. G., and M. L. Hunter Jr. 1998. Effects of silvicultural edges on the distribution and abundance of amphibians in Maine. Conservation Biology 12:340-352.

Didham, R. K. $1997 a$. An overview of invertebrate responses to forest fragmentation. Pages 304-319 in A. D. Watt, N. E. Stork, and M. D. Hunter, editors. Forests and insects. Chapman \& Hall, London

Didham, R. K. 1997 b. The influence of edge effects and forest fragmentation on leaf litter invertebrates in central Amazonia. Pages 55-70 in W. F. Laurance and R. O. Bierregaard Jr., editors. Tropical forest remnants: ecology, management, and conservation of fragmented communities. The University of Chicago Press, Chicago

Didham, R. K., J. Ghazoul, N. E. Stork, and A. J. Davis. 1996. Insects in fragmented forests: a functional approach. Trends in Ecology and Evolution 11:255-260.

Donovan, T. M., P. W. Jones, E. M. Annand, and F. R. Thompson III. 1997. Variation in local-scale edge effects: mechanisms and landscape context. Ecology 78:2064-2075.

Esseen, P.A., E. Ehnström, L. Ericson, and K. Sjöberg, 1997. Boreal forests. Ecological Bulletins 46:16-47.

Greenslade, P. J. M. 1964. Pitfall trapping as a method for studying populations of Carabidac (Colcoptera). Journal of Animal Ecology 33:301-310

Haila, Y. 1999. Islands and fragments. Pages 234-264 in M. L. Hunter Jr., editor. Maintaining biodiversity in forest ecosystems. Cambridge University Press, Cambridge, United Kingdom.

Haila, Y., I. K. Hanski, J. Niemelä, P. Punttila, S. Raivio, and H. Tukia. 1994. Forestry and boreal fauna: matching management with natural forest dynamics. Annales Zoologici Fennici 31:187-202.

Halme, E., and J. Niemelä. 1993. Carabid beetles in fragments of coniferous forest. Annales Zoologici Fennici 30:17-30.

Hänggi, A., and B. Baur. 1998. The effect of forest edge on ground-living arthropods in a remnant of unfertilized calcareous grassland in the Swiss Jura mountains. Mitteilungen der Schweizerischen Entomologischen Gesellschaft, Bulletin de la Société Entomologique Suisse $71: 343-354$

Harris, 1. D. 1984. The fragmented forest: island biogeography theory 
and the preservation of biotic diversity. University of Chicago Press, Chicago.

Helle, P., and J Muona. 1985. Invertebrate numbers in edges between clear-fellings and mature forests in Northern Finland. Silva Fennica 19:281-294

Jokimäki, J., E. Huhta, J. Itämies, and P. Rahko. 1998. Distribution of arthropods in relation to forest patch size, edge, and stand characteristics. Canadian Journal of Forest Research 28:1068-1072.

Jongman, R. H. G., C. J. F. Ter Braak, and O. F. R. Van Tongeren, editors. 1995. Data analysis in community and landscape ecology. Cambridge University Press, Cambridge, United Kingdom.

Kapos, V. 1989. Effects of isolation on the water status of forest patches in the Brazilian Amazon. Journal of Tropical Ecology 5: 173-185.

Kotze, D. J., and M. J. Samways. 1999. Invertebrate conservation at the interface between the grassland matrix and natural Afromontane forest fragments. Biodiversity and Conservation 8:1339-1363.

Krebs, C. J. 1989. Ecological methodology. Harper \& Row, New York.

Kruger, S. C., and M. J. Lawes. 1997. Edge effects at an induced forestgrassland boundary: forest birds in the Ongoye Forest Reserve, KwaZulu-Natal. South African Journal of Zoology 32:82-91.

Lindroth, C. H. 1985. The Carabidae (Coleoptera) of Fennoscandia and Denmark. Fauna Entomologica Scandavica 15(1):1-225.

L.indroth, C. H. 1986. The Carabidae (Coleoptera) of Fennoscandia and Denmark. Fauna Entomologica Scandinavica 15(2):233-497.

Ludwig, J. A., and J. F. Reynolds 1988. Statistical ecology. Wiley, New York.

Magura, T., and B Tothmeresz. 1997. Testing edge effect on carabid assemblages in an oak-hornbeam forest. Acta Zoologica Academiae Scientarum Hungaricae 43:303-312.

Matjack, G. R., and J. A. Litvaitis. 1999. Forest edges. Pages 210-233 in M. L. Hunter Jr., editor. Maintaining biodiversity in forest ecosystems. Cambridge University Press, Cambridge, United Kingdom.

Meiners, S. J., and S. T. A. Pickett. 1999. Changes in community and population responses across a forest-field gradient. Ecography 22: $261-267$

Murcia, C. 1995. Edge effects in fragmented forests: implications for conservation. Trends in Ecology and Evolution 10:58-62.

Niemelä, J. 1993. Mystery of the missing species: species-abundance distribution of boreal ground-beetles. Annales Zoologici Fennici 30:169-172.

Niemelä, J. 1997. Invertebrates and boreal forest management. Conservation Biology 11:601-610.

Niemelä, J., Y. Haila, E. Halme, T. Lahti, T. Pajunen, and P. Punttila. 1988. The distribution of carabid beetles in fragments of old coniferous taiga and adjacent managed forest. Annales Zoologici Fennici 25:107-119.

Niemelä, J., D. Langor, and J. R. Spence. 1993. Effects of clear-cut harvesting on boreal ground-beetle assemblages (Coleoptera: Carabidae) in western Canada. Conservation Biology 7:551-561.

Niemelä, J., J. R. Spence, D. Langor, Y. Haila, and H. Tukia. 1994. Logging and boreal ground-beetle assemblages on two continents: implications for conservation. Pages 29-50 in K. Gaston, M. Samways, and $T$. New, editors. Perspectives in insect conservation. Intercept Publications, Andover, Massachusetts.

Pajunen, T., Y. Haila, E. Halme, J. Niemelä, and P. Punttila. 1995.
Ground-dwelling spiders (Arachnicla, Araneae) in fragments of old forest and surrounding managed forests in southern Finland. Ecography 18:62-72.

Peltonen, M., and K. Heliövaara. 1998. Incidence of Xelechinus pilosus and Cryphalus saltuarius (Scolytidae) in forest-clearcut edges. Forest Ecology and Management 103:141-147.

Punttila, P., Y. Haila, T. Pajunen, and H. Tukia. 1991. Colonisation of clearcut forests by ants in the southern Finnish taiga: a quantitative survey. Oikos 61:250-262.

Punttila, P., Y. Haila, J. Niemelä, and T. Pajunen. 1994. Ant communities in fragments of old-growth taiga and managed surroundings. Annales Zoologici Fennici 31:131-144.

Ranney, J. W., M. C. Bruner, and J. B. Levenson. 1981. The importance of edge in the structure and dynamics of forest islands. Pages $67-$ 96 in R. L. Burgess and D. M. Sharpe, editors. Forest islands dynamics in man-dominated landscapes. Springer Verlag, New York.

Ranta, P., T. Blom, J. Niemelä; E. Joensuu, and M. Siitonen. 1998. The fragmented Atlantic rain forest of Brazil: size, shape and distribution of forest fragments. Biodiversity and Conservation 7:385-403.

Rassi, P., H. Kaipiainen, I. Mannerkoski, and G. Stảhls. 1992. Report on the monitoring of threatened animals and plants in Finland. Komiteamietintö 1991: 30. Ympäristöministeriö, Helsinki (in Finnish with English summary).

Risser, P. G. 1995. The status of the science of examining ecotones. Bioscience 45:318-325.

Saunders, D. A., R. J. Hobbs, and C. R. Margules. 1991. Biological consequences of ecosystem fragmentation: a review. Conservation Biology 5:18-32.

Siitonen, J., and P. Martikainen. 1994. Occurrence of rare and threatened insects living on decaying Populus tremula: a comparison between Finnish and Russian Karelia. Scandinavian Journal of Forest Research 9:185-191.

Spence, J. R., and J. Niemelä. 1994. Sampling carabid assemblages with pitfall traps: the madness and the method. Canadian Entomologist 126:881-894.

Spence, J. R., D. Langor, J. Niemelä, H. Cárcamo, and C. Currie. 1996. Northern forestry and carabids: the case for concern about oldgrowth species. Annales Zoologici Fennici 33:173-184.

Stevens, S. M., and T. P. Husband. 1998. The influence of edge on small mammals: evidence from Brazilian Atlantic forest fragments. Biological Conservation 85:1-8.

ter Braak, C. J. F., and P. Smilauer. 1998: CANOCO for Windows. Version 4.0. Centre for Biometry, Wageningen, The Netherlands.

Usher, M. B., J. P. Field, and S. E. Bedford. 1993. Biogeography and diversity of ground-dwelling arthropods in farm woodlands. Biodiversity Letters 1:54-62.

Väisänen, R. 1995. Perhoset. Pages 103-108 in S. Raivio, editor. Talousmetsien luonnonsuojelu-yhteistutkimushankkeen väliraportti. Metsähallinnon Luonnonsuojelujulkaisuja, sarja A, 43 (in Finnish).

Voller, J. 1998. Managing for edge effects. Pages 215-233 in J. Voller and S. Harrison, editors. Conservation biology principles for forested landscapes. University of British Columbia Press, Vancouver, Canada.

von Sacken, A. 1998. Interior habitat. Pages 130-145 in J. Voller and S. Harrison, editors. Conservation biology principles for forested landscapes. University of British Columbia Press, Vancouver, Canada.

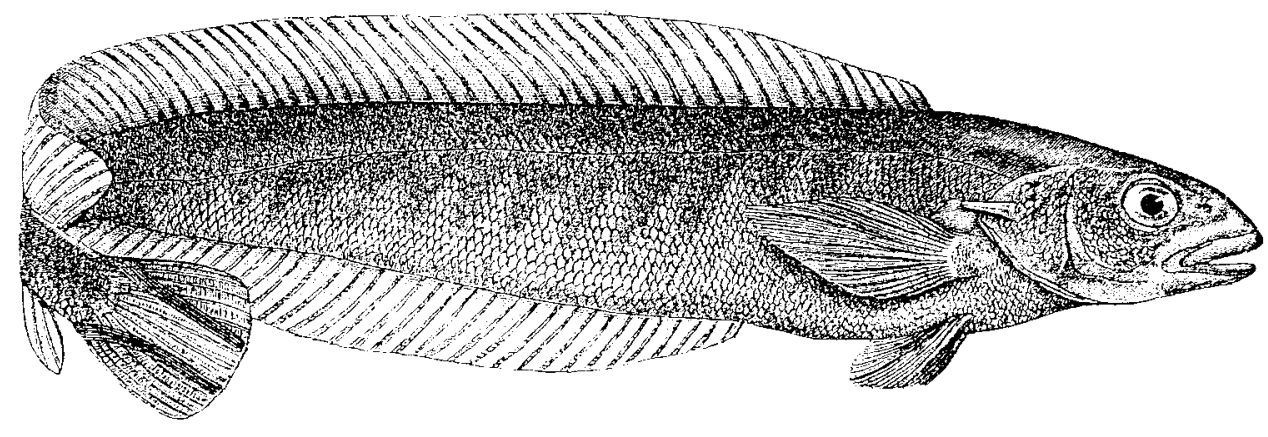

